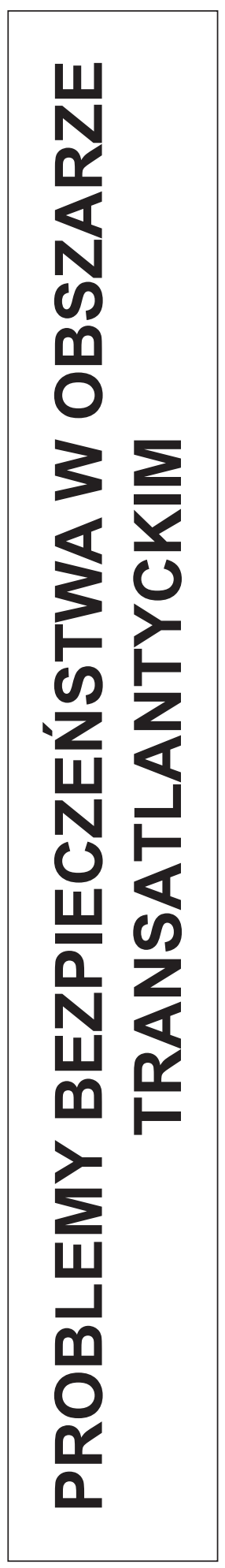



DOI $10.14746 /$ ps.2015.1.2

\section{GRANICA I POGRANICZE UNII EUROPEJSKIEJ I ROSJI. W POSZUKIWANIU NOWYCH SCHEMATÓW INTERPRETACYJNYCH ${ }^{1}$}

Intencją szczytu Partnerstwa Wschodniego odbywającego się 28-29 listopada 2013 r. w Wilnie była finalizacja długotrwałych wysiłków Unii Europejskiej na rzecz ustanowienia nowych relacji ze wschodnimi sąsiadami, przede wszystkim za pomocą umów stowarzyszeniowych. W przypadku Ukrainy spowodowało to reakcję Rosji, zmianę decyzji ukraińskiego przywództwa, następnie krwawe protesty w Kijowie zorganizowane przez prozachodnio nastawione społeczeństwo, i ostatecznie usunięcie prezydenta Wiktora Janukowycza. Jego obalenie doprowadziło do rosyjskiej inwazji na Krymie i wsparcia dla prorosyjskich separatystów, a następnie gwałtownego i krwawego konfliktu we wschodnich rejonach Ukrainy. Wszystkie te wydarzenia, ku zaskoczeniu wielu polityków i ekspertów, drastycznie zreorganizowały nie tylko sytuację polityczną, ale także charakter stosunków granicznych między UE i Rosją, które wcześniej pozytywnie rozwijały się przez dwie dekady po upadku komunizmu w Europie.

Celem niniejszej pracy jest przedstawienie nowego podejścia do zrozumienia bieżących stosunków granicznych między Unią Europejską a Rosją lub - bardziej precyzyjnie - między projektem europejskim a projektem rosyjskim. Pierwszy z nich rozumiany jest tutaj znacznie szerzej niż sama Unia Europejska, zawiera także wiele form relacji pomiędzy Unią a państwami z nią sąsiadującymi (Jańczak, 2010). Drugi zawiera także szerszą formułę niż tylko Federacja Rosyjska, uwzględniając wielowymiarowe zależności w przestrzeni poradzieckiej. Proponowane nowe podejście zamierza rozpocząć wyjaśnianie dynamiki granicznej między nimi przez zastosowanie klasycznych podejść w studiowaniu granic. Autor założył, że zmieniające się okoliczności polityczne, gospodarcze i społeczne w tej części kontynentu europejskiego podważają wartość dominujących paradygmatów w studiach nad granicami i badaniu granic (Agnew, 2003; Klatt, Hayo, 2011; Scott 2013), co zmusza badaczy do poszukiwania nowych instrumentów wyjaśniania. Ponieważ nowy model relacji oparty jest o konkurencję, a nawet konflikt i konfrontację, a nie współpracę, przypomina on sytuację graniczną dominującą w Europie przed końcem zimnej wojny (Jones, 1959; Newman, 2003). W związku z tym podejścia analityczne dominujące w owym czasie, w szczególności

1 Niniejszy artykuł jest wynikiem badań w ramach międzynarodowego projektu badawczego Boundaries Revisited. Conceptual Turn in European Border Practices i w wersji angielskiej publikowany został jako J. Jańczak (2015), The EU-Russian Border. Classical Concepts Revisited, w: Boundaries Revisited. A Conceptual Turn in European Border Practices, (eds.) T. Brańka, J. Jańczak, Berlin. 
pojęcia granicy jako boundary, imperium, ekspansji terytorialnej itd., mogą być przydatne w zrozumieniu obecnej sytuacji (Jańczak, 2013).

W prezentowanym tekście, autor pokrótce przedstawia najważniejsze wymiary rozumienia instytucji granicy, aplikuje je do przypadku Unii Europejskiej, szczególnie w okresie od roku 1995 (wyznaczonego przez drugie rozszerzenie północne UE, ale także rozpoczęcie procesu barcelońskiego) do 2014 r. (początek napięć granicznych na Ukrainie), a następnie podejmuje próbę różnych interpretacji obecnej sytuacji między dwoma przywołanymi projektami integracyjnymi.

\section{GRANICE: FRONTIER I BOUNDARY - ZMIENIAJĄCE SIĘ MODELE I PARADYGMATY}

Dynamika relacji granicznych może zostać scharakteryzowana poprzez obecność lub nawet dominację jednej z dwóch form granic, mianowicie frontier bądź boundary (Kristof, 1959). Formy te mówią wiele o aktualnych stosunkach granicznych, ale także o sąsiadujących strukturach politycznych, organizacji państw lub innych jednostek polityczno-terytorialnych.

Granica jako frontier jest zazwyczaj definiowana jako przestrzeń między państwami, gdzie mieszają się wpływy, kultury itd. (Walters, 2004: 687-688; Browning, Joenniemi, 2008: 529). W konsekwencji jest to „strefa kontaktu między dwoma podmiotami lub systemami społecznymi” (Evans, Newnham, 1998: 185), a nawet „ziemia niczyja” (Alkan, 2002: 34). Często jest zamieszkana przez „ludzi pogranicza” (borderlanders), reprezentujących cechy dominujące w obu sąsiednich strukturach (O'Dowd, Wilson, 2002: 8). Tak rozumiane granice są początkami „właściwych terytoriów”, zwykle o dość otwartym charakterze.

$\mathrm{Z}$ drugiej strony, granica rozumiana jako boundary jest linią, która „wyznacza mniej lub bardziej precyzyjne ograniczenia terytorium" (Evans, Newnham, 1998: 185). Jest ona dobrze ustrukturyzowana i zorganizowana (Germond, 2010: 39), definiuje wyłączne suwerenności (O’Dowd, Wilson, 2002: 8). Jak zauważa Ladis Kristof, boundary „wyznacza określone, dobrze ustanowione limity (wewnętrznie wiążące) danej jednostki politycznej, i wszystko, co jest wewnątrz granicy, jest ze sobą powiązane, to znaczy, że jest połączone wewnętrznymi zależnościami” (Kristof, 1959: 269-270). Tak zdefiniowana granica oznacza w konsekwencji „koniec” terytorium.

Granice w rozumieniu frontier dominowały w polityczno-terytorialnym krajobrazie Europy przed pokojem westfalskim. Proces tworzenia państw narodowych krok po kroku je boundaryzowat. Integracja europejska i później postzimnowojenne procesy odkryły granice typu frontier na nowo dla ładu przestrzennego-politycznego Europy, zwłaszcza w obrębie i wokół Unii Europejskiej.

\section{GEOSTRATEGIE UNII EUROPEJSKIEJ}

Po powyższej krótkiej analizie charakteru granic, koniecznym jest spojrzenie na sposób, w jaki mogą być one skonstruowane. Christopher Browning i Pertti Joenniemi 
(2008) opisują cztery rodzaje geostrategii, aplikując je do przypadku Unii Europejskiej: networked (non)border, march, colonial frontier i limes (Schemat 1).

\section{Schemat 1. Geostrategie Unii Europejskiej}

EU

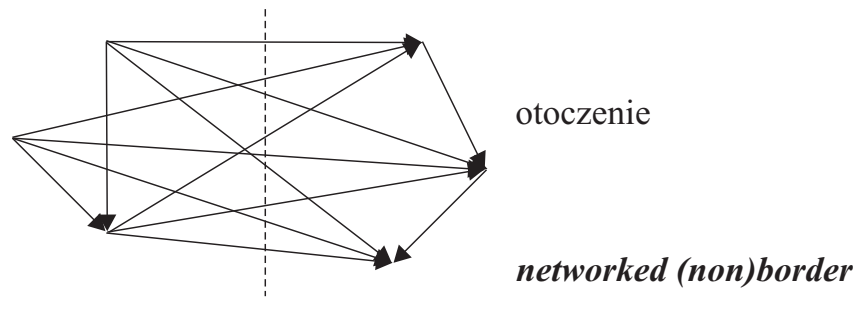

UE

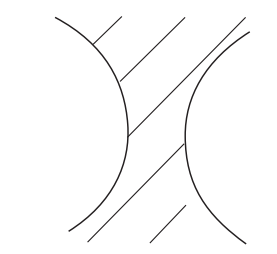

otoczenie

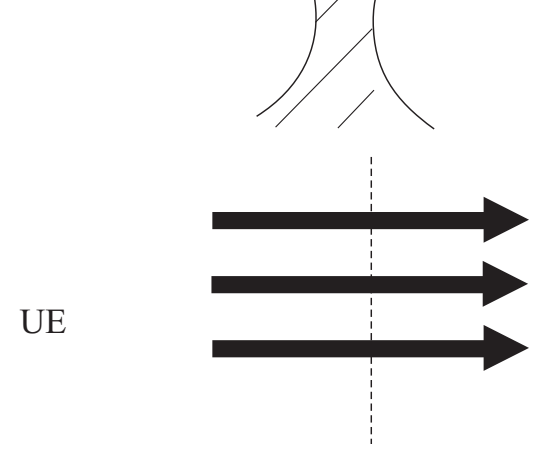

march

otoczenie

colonial frontier

UE

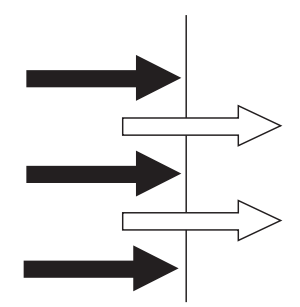

otoczenie

limes

Źródło: Browning, Joenniemi, 2008: 528.

W przypadku networked (non)border fizyczne granice stają się coraz mniej istotne, a swobodny przepływ osób i dóbr oznacza dzielenie odpowiedzialności za swobodną cyrkulację przez różne centra. March jest strefą buforową, oddzielającą dwa podmioty (Browning, Joenniemi, 2008: 527; Walters, 2004). Colonial frontier to dynamiczna linia, która oddziela asymetryczne struktury. Jest ona jednak przepuszczalna, pozwalając na jednokierunkowy transfer norm, wartości i rozwiązań, od bardziej zaawansowanego partnera ku mniej rozwiniętym. Sama linia jest przesuwana, co dzieje się wraz z absorpcją terytoriów, na które wcześniej wywierano wpływ. Wreszcie limes, będące także rodzajem linii między asymetrycznymi strukturami, choć o ostatecznym (statycznym) charakterze (Browning, Joenniemi, 2008: 529; Walters, 2004). 
W przypadku Unii Europejskiej, wraz z rozwojem Europejskiej Polityki Sasiedztwa (ang. European Neighbourhood Policy), zastosowanie różnych geostrategii widoczne jest na poszczególnych fragmentach zewnętrznej granicy UE. Na północy wydaje się dominować networked (non)border. Na wschodzie był to jeszcze niedawno colonial frontier, co przejawiało się próbami stabilizacji i europeizacji sąsiadów (i ewentualną perspektywą ich członkostwa w odległej przyszłości). Na południu występują elementy limes i ostateczna granica UE (Browning i Joenniemi, 2008: 544-545).

\section{MODELE GEOPOLITYCZNE UNII EUROPEJSKIEJ}

Spojrzenie na sposób kształtowania stosunków granicznych umożliwia uzyskanie bardziej ogólnego obrazu modelu geopolitycznego reprezentowanego przez Unię Europejską. Ponownie Christopher Browning i Pertti Joenniemi (2008) definiują trzy schematy: westfalski (Westphalian), imperialny (imperial) i neośredniowieczny (neomedieval) (Schemat 2).

Model westfalski stał się podstawą dla tworzenia państw narodowych w tradycyjnym ich rozumieniu, ze zdefiniowanym terytorium „uwięzionym” w precyzyjnie zdefiniowanych granicach państwowych. Centrum kontrolowało całe terytorium w podobnym zakresie, eksportując normy, wartości, prawa i rozwiązania na peryferie. Logika westfalska zastosowana dla zdefiniowania charakteru Unii Europejskiej zakłada, że reprezentuje ona jednostkę semipaństwową, o strukturze podobnej do klasycznego państwa narodowego (Caporaso, 1996). Obszar ograniczony przez granicę zewnętrzną (szczególnie granicę Schengen) konstytuuje przestrzeń równego obowiązywania acquis communitaire (regulującego zarówno cztery swobody jednolitego rynku, ale zawierającego jednocześnie normatywny szkielet wartości europejskich), z centrum politycznym UE przejmującym stopniowo kompetencje państw członkowskich (Browning, Joenniemi, 2008: 522-526).

W przypadku modelu imperialnego, centrum i obrzeża są łatwo zauważalne, przede wszystkim z uwagi na jednokierunkowy charakter relacji pomiędzy nimi. Centrum wpływa na peryferie, jednak im dalej od centrum, tym słabsze jest jego promieniowanie. Centrum jest w konsekwencji otoczone koncentrycznymi kręgami coraz słabiej zależnych terytoriów. W tym modelu jednakże wewnętrzne i zewnętrzne kręgi mogą być stopniowo wchłaniane przez centrum, a jednocześnie pojawiają się nowe kręgi, jako że imperia mają tendencję do dalszego rozrostu. Rozszerzają one swój wymiar terytorialny poprzez eksport norm, wartości, ale także tradycyjnych środków sprawowania władzy. Przejawy imperialnego modelu w przypadku UE widoczne są zarówno w rozszerzeniach, ale także w zaangażowaniu zewnętrznym (Zielonka, 2007), np. w zewnętrznej demokratyzacji, jak widać w Europejskiej Polityce Sasiedztwa (Browning, Joenniemi, 2008: 522-526).

W przypadku modelu neośredniowiecznego nie można zidentyfikować jednego dominującego centrum, kompetencje i władza zlokalizowane są w wielu ośrodkach, które współdziałają ze sobą (Wind, 2003). Koncepcja zarządzania (governance) charakteryzuje sposób, w jaki decyzje są podejmowane, w funkcjonalnie zorientowanej sieci współdziałających centrów (Browning, Joenniemi, 2008: 522-526). 
Schemat 2. Modele geopolityczne Unii Europejskiej
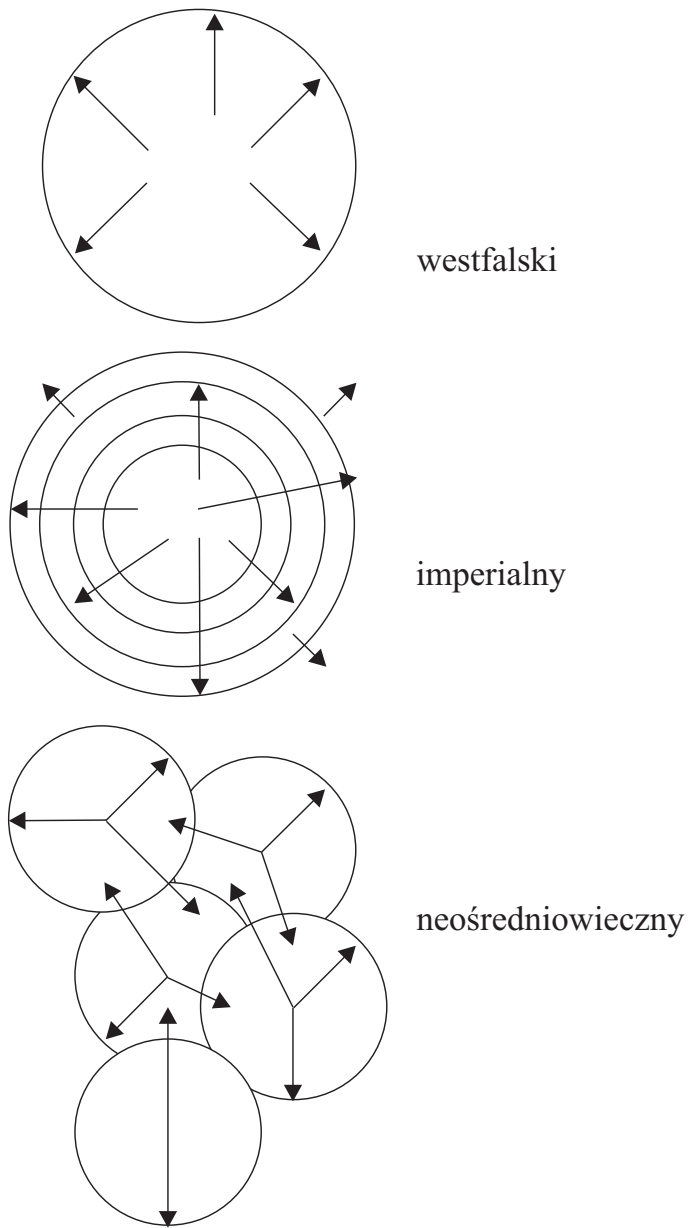

Źródlo: Browning, Joenniemi, 2008: 523.

Przedstawiwszy powyższe modele, zasadnym jest zastosowanie ich do analizy zmian granicznych na wschodnim pograniczu Unii Europejskiej. Zdaniem autora modele w przywołanej formie są zbyt statyczne, aby przekonująco wyjaśnić dokonujące się tam procesy, zwłaszcza ze względu na fakt, że są one monocentrycznie zorientowane i ignorują sytuację w otoczeniu UE. Słabość ta może być łatwo wyeliminowana przez zastosowanie podejścia policentrycznego.

\section{IMPLEMENTACJA MODELU - OD PODEJŚCIA MONOCENTRYCZNEGO DO POLICENTRYCZNEGO}

Aplikując przedstawione geostrategie i modele geopolityczne do przypadku Unii Europejskiej, można zidentyfikować dwie fazy strukturyzowania granicy. Pierwsza 
widoczna była pomiędzy upadkiem komunizmu w Europie a wileńskim szczytem Partnerstwa Wschodniego w listopadzie 2013 r. (Tolksdorf, 2013). Faza ta charakteryzuje się erozją granic w rozumieniu bundary i pojawianiem się lub odtwarzaniem granic frontier. Druga faza została zainicjowana przez polityczny i wojskowy konflikt na Ukrainie (początkowo objawiający się jako kwestia wewnętrzna, ostatecznie stając się elementem gry o wymiarze kontynentalnym), podważając wcześniejszy rozwój relacji granicznych i potwierdzając zmienny charakter granic w Europie.

\section{Okres postzimnowojenny}

Wewnętrzne zróżnicowanie Unii Europejskiej po roku 2004, a także jej zaangażowanie w regionach bezpośredniego sąsiedztwa mogą być uważane za elementy klasyfikujące ją jako strukturę zorganizowaną według modelu imperialnego. Teza taka wymaga jednak krótkiego uzasadnienia (Duke, 2004).

Rozszerzona Unia Europejska, składająca się z 25, 27 i wreszcie 28 państw członkowskich, musiała zmierzyć się z problemem identycznego schematu dalszej integracji dla wszystkich lub stosowania różnych modeli dla państw członkowskich. Zasada warunkowości (ang. conditionality), a tym samym konieczność przyjęcia w ramach kryteriów kopenhaskich całości acquis communautaire, uważana była za podstawę dynamiki integracji i monolitycznego charakteru projektu integracyjnego. Jednakże w tym samym czasie różne wizje, ale także możliwości dalszego rozwoju Unii Europejskiej wywołały ożywioną debatę na temat integracji, dzięki czemu państwa członkowskie mogły uczestniczyć w projekcie z różnym stopniem intensywności. $Z$ jednej strony, możliwość wykonania dalszych kroków integracyjnych została zawarta w mechanizmie wzmocnionej współpracy. Z drugiej jednak, niektóre z państw członkowskich nie mogły lub nie chciały uczestniczyć w pewnych formach integracyjnych, takich jak strefa Schengen czy strefa euro. Efektem stała się refleksja akademicka na temat integracji elastycznej, proponująca modele Europy wielu prędkości, zmiennej geografii, a la carte itd. (Szymczyński, 2002). Politycznie widoczna w koncepcjach, nie tylko w EUropy, ale także EUROpy.

Podobnie relacje z unijnym otoczeniem zostały skonstruowane w porównywalnej dynamice. Państwa sąsiedzkie otrzymywały zróżnicowane propozycje dotyczące form ułożenia wzajemnych stosunków. Niektóre z nich stały się kandydatami, inne uznano za potencjalnych kandydatów, obie kategorie obecne były zwłaszcza na obszarze Zachodnich Bałkanów i w pobliżu na południowo-wschodniej granicy UE. Innym zaoferowano szczególne stosunki, stowarzyszenie lub partnerstwo. Inicjatywy regionalne, takie jak Wymiar Północny (Ojanen, 1999) czy proces barceloński (Bernatowicz, 2005; Suel, 2008) doprowadziły do instytucjonalizacji polityki UE skierowanej do swoich sąsiadów w postaci Europejskiej Polityki Sasiedztwa (Comelli, Greco, Tocci, 2007).

Opisana powyżej dynamika doprowadziła do Unii Europejskiej (lub raczej projektu europejskiego) w kształcie, który daje się dobrze opisać za pomocą modelu imperialnego (Zielonka, 2007). Opiera się ona o logikę koncentrycznych okręgów, w których twardy rdzeń tworzony jest przez grupy państw członkowskich, które osiagnęły najwyższy poziom integracji, uczestnicząc we wszystkich formach instytucjonalnych i pozin- 
stytucjonalnych projektu. Im dalej od centrum, tym mniej intensywny udział (Comelli, Greco, Tocci, 2007). W ten sposób kręgi zewnętrzne reprezentują państwa członkowskie niebędące częścią strefy euro, potem strefy Schengen, następnie nie-członków oczekujących na członkostwo i prowadzących negocjacje akcesyjne, dalej te chętne do negocjacji w przyszłości, w końcu państwa partnerskie z - wynikającym między innymi z braku mechanizmów warunkowości - znacznie słabszym wpływem centrum UE.

Efektem opisanej dynamiki są trzy istotne konsekwencje.

Po pierwsze, wskazują one na ekspansywny charakter projektu UE, ukazujący neofunkcjonalną linearność (Lindberg, 1963) terytorialnej logiki spill over. Projekt europejski przyciaga coraz więcej państw położonych dalej i dalej od pierwotnego centrum. Powoduje to rozrost Unii Europejskiej, gdzie jednak charakter powiązań „,nowowchłanianych" obszarów jest tym słabszy, im dalej znajdują się one od centrum.

\section{Schemat 3. Ekspansja Unii Europejskiej}

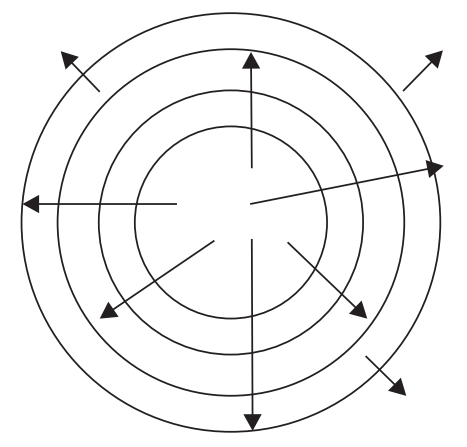

Źródło: Opracowanie własne.

Po drugie, granice przestrzenne projektu europejskiego są znacznie szersze niż granice UE. Ponadto wpisują się one bardziej w schemat frontier niż boundary. Są one rozmyte i nieokreślone, ich położenie ciagle się zmienia, są przesuwane coraz dalej. Geostrategia colonial frontier dobrze opisuje ich charakter, zwłaszcza w części wschodniej, gdzie biorąc pod uwagę sąsiednie przestrzenie jako obszar ekspansji, UE eksportuje normy i wartości jako potęga normatywna, dla stabilizacji, demokratyzacji i rozwoju zewnętrznych okręgów.

Po trzecie, zarówno refleksja naukowa i praktyka polityczna projektu europejskiego są silnie zorientowane na Europę i są europocentryczne. Zakładają one (bezpośrednio lub pośrednio), że UE jest wyróżniającym się, a nawet jedynym istniejącym projektem w tej części świata, będąc rodzajem przestrzeni cywilizacji otoczonej „barbarzyńskimi” i/lub „niezagospodarowanymi” terytoriami. Ta asymetria w stosunkach wzajemnych wynika $\mathrm{z}$ jednej strony $\mathrm{z}$ wysokiego poziomu rozwoju gospodarczego (PKB) i politycznego (liberalna demokracja) UE (i jej państw członkowskich), jak i niskiego panującego wokół jej granic. Z drugiej jednak strony, z braku alternatywy środki ciężkości znajdują się w sąsiedztwie. W związku z tym, projekt europejski był przez długi czas rozwijany w otoczeniu ziemi niczyjej, podlegając nieograniczenie ekspansji w kierunku zewnętrznych przestrzeni. 


\section{Rozwój sytuacji w okresie po szczycie wileńskim}

Opisana powyżej faza relacji granicznych zakończyła się wraz ze szczytem wileńskim Partnerstwa Wschodniego w listopadzie 2013 r., kiedy po raz pierwszy od dwóch dekad ekspansja Unii Europejskiej została zatrzymana przez czynnik zewnętrzny (Sekerev, 2013). Była nim alternatywna struktura integracyjna - Federacja Rosyjska zmierzająca do (re)integracji (części) przestrzeni postsowieckiej.

Partnerstwo Wschodnie zostało zaproponowane jako wspólna inicjatywa Polski i Szwecji w roku 2008 (Milczarek, 2006; Cinciara, 2008), ale opierało się na wcześniejszych pomysłach (Kowal, 2002). Zostało ono skierowane do sześciu państw byłego Związku Radzieckiego: Białorusi, Ukrainy, Mołdawii, Gruzji, Azerbejdżanu i Armenii. Miało na celu zawiązanie ścisłej współpracy, jednakże bez perspektywy członkostwa (Youngs, Pishchikova, 2013). Jednocześnie jednak, w oczach niektórych wschodnich członków UE, Partnerstwo jawiło się od samego początku jako pierwszy krok pełnej integracji niektórych państw partnerskich z Unią Europejską w (dalekiej) przyszłości (Bednarek, 2003).

Wschodnia ekspansja UE zderzyła się z odradzającymi się imperialnymi ambicjami Rosji, która doświadczała właśnie wewnętrznej konsolidacji pod rządami Władimira Putina (Delcour, Wolczuk, 2013). (Re)centralizacja władzy i jej koncentracja w rękach nowych elit w Kremlu znacznie wzmocniła państwo po latach smuty. Rozwój gospodarczy, oparty głównie na eksporcie gazu i ropy naftowej, wyposażył Rosję w środki pozwalające na reaktywację projektu imperium rosyjskiego. Umożliwiło to pokonanie efektów „największej katastrofy geopolitycznej ubiegłego wieku” - upadku Związku Radzieckiego i jego dezintegracji terytorialnej. Inicjatywa Euroazjatyckiej Wspólnoty Gospodarczej (Krotov, 2011) została w 2015 r. zastapiona nowym projektem, Euroazjatyckq Uniq Gospodarcza (Blockmans, Hranta, Vorobiov, 2012), która miała przyspieszyć intensywną integrację, kopiując w znacznym stopniu wzorce zachodnie. Jej członkami zostały Rosja, Białoruś i Kazachstan, a także Armenia i Kirgistan. Ważnym jest odnotowanie faktu, iż takie podejście zrywa z perspektywą europocentryczną, postrzegającą UE jako jedyny projekt rozwijany w otaczającej go próżni.

Przedstawiony powyżej kontekst pozwala na przedstawienie kilku interpretacji widocznego obecnie ,przesunięcia” w relacjach granicznych na obrzeżach UE, tak w zakresie koncepcyjnym, jak i empirycznym, a tym samym do opracowania różnych scenariuszy na przyszłość.

Pierwsze z możliwych podejść zakłada, że konflikt na Ukrainie pojawił się w wyniku nakładających się wpływów dwóch konkurencyjnych ośrodków: Brukseli i Moskwy (Schemat 4). Oba centra starają się eksportować swoje własne projekty integracyjne do sąsiedzkich obszarów, z zewnętrznymi kręgami będącymi w coraz mniejszym stopniu - ale nadal z nimi powiązanymi. Ukraina może być uznana za granicę typu frontier, przestrzeń, w której wpływy polityczne, gospodarcze i kulturalne UE i FR zachodzą na siebie. Taka sytuacja była akceptowalna przez obie strony, jednak z różnych powodów. UE, a dokładniej wiele z jej państw członkowskich (zwłaszcza w zachodniej części kontynentu), nie była w stanie lub nie chciała zaproponować członkostwa (lub podobnego rozwiązania) będąc usatysfakcjonowana sytuacją, w której jej wschodni sąsiad pozostał rodzajem march (w praktyce strefą buforowa). Rosja $\mathrm{z}$ kolei nie potrafiła za- 
pobiec prozachodniemu zorientowaniu Ukrainy (począwszy od pomarańczowej rewolucji, a kończąc na stopniowo zacieśnianych relacjach między UE i Ukrainą). Obie strony traktowały ją jako colonial frontier, co oznaczało czasami rodzaj march, rozdzielającego obie strony. W tym samym czasie, zwiększająca się współpraca Ukrainy i Unii Europejskiej wykazywała ekspansywny charakter tej drugiej.

\section{Schemat 4. Poszerzająca się Unia Europejska vs. rekonstrukcja imperium (sowiecko-) rosyjskiego}
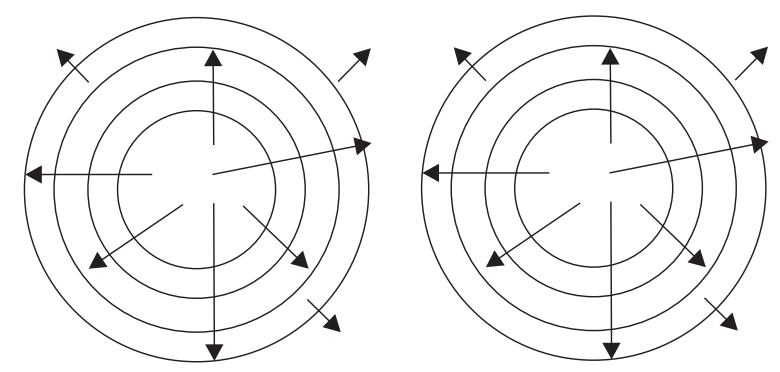

Źródło: Opracowanie własne.

Konflikt wynikający z wycofania się rządu Wiktora Janukowycza z uprzednio przygotowanej umowy stowarzyszeniowej pokazał jednak wyczerpanie się takiego postrzegania wzajemnych relacji i relacji granicznych przez obie strony. Dalsza ekspansja zarówno UE (w formie stowarzyszenia i, być może w dalekiej przyszłości, debaty na temat członkostwa), jak i Rosji (podejście widoczne w projekcie Euroazjatyckiej Unii Gospodarczej) stały się nagle wzajemnie wykluczające. Mniej zaawansowane formy wpływów pozwalały na zachowanie frontier (a nawet $\mathrm{march}$ ). Ekspansja spowodowała konieczność podjęcia decyzji opartej na zasadzie zerojedynkowej. Doprowadziło to do (re-)boundaryzacji granicy między projektem europejskim a projektem rosyjskim.

Zaproponowana powyżej perspektywa powoduje jednak konieczność ponownego określenia charakteru obu projektów. Charakter wyłączności i potencjał konfliktowy koresponduje z opisanym wcześniej modelem westfalskim (Caporaso, 1996). Tutaj, obie konstrukcje (zwłaszcza UE) nie mogą dalej rozwijać się terytorialne, blokując się wzajemnie. Nakładające się na siebie wpływy nie są już możliwe, w związku z tym wzajemne relacje muszą doprowadzić do ustanowienia granicy typu boundary pomiędzy obiema strukturami (Schemat 5.). Ukraina może należeć tylko do projektu europejskiego lub tylko do projektu rosyjskiego. Dotyczy to terytorium całego państwa (jako rozwiązanie preferowane zarówno przez UE, jak i Rosję), ale może również prowadzić do dezintegracji i podziału na zachodnią (pro-europejska) Ukrainę oraz wschodnią (prorosyjską) Noworosję.

Taka interpretacja musi prowadzić do konfliktu, ale także do wytyczenia wyraźnej granicy typu boundary między oboma projektami z geostrategią limes zastosowaną przez obie strony. Ta nowa granica powinna być „ostateczna”, izolując je od - w rozumieniu obu stron - barbarzyńskich wrogów znajdujących się z drugiej strony. Stanie się więc końcem przestrzeni europejskiej i rosyjskiej, odpowiednio, na ich wschodzie i na zachodzie. Dalszy rozwój struktur w obu przypadkach powinien być możliwy tylko 
Schemat 5. Unia Europejska jako ukończony projekt vs. rosyjskie tworzenie państwa narodowego
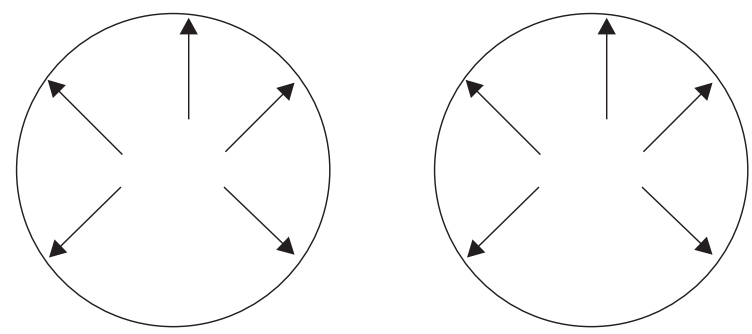

Źródło: Opracowanie własne.

w innych kierunkach, ponownie, tak długo, jak opisywane projekty nie natrafią na kolejne alternatywne ośrodki oddziaływania. W praktyce oznacza to Bałkany Zachodnie w przypadku pierwszego i Azję Centralą w przypadku drugiego projektu.

Przedstawiona argumentacja może zostać jednak poddana krytyce z uwagi na fakt, iż nie bierze ona pod uwagę wewnętrznej złożoności obu projektów integracyjnych.

W przypadku Unii Europejskiej problem ten związany jest z charakterem jej struktury. Nie jest ona państwem, w dalszym ciągu można uznać ją za organizację międzynarodową, gdzie pomimo silnych elementów ponadnarodowych, nadal dominuje międzyrządowy model we wzajemnych relacjach, zwłaszcza w odniesieniu do polityki zewnętrznej i bezpieczeństwa (Berg, Ehki, 2007). W związku z tym, nie ma jednego centrum, istnieje raczej sieć centrów wzajemnie wpływających na siebie, jednak często reprezentujących różne interesy i wizje (Wind, 2003). Ostatnie rozszerzenia pogłębiły tę tendencję, różnicując skład Unii Europejskiej. Inicjatywy zewnętrzne, takie jak Europejska Polityka Sasiedztwa czy też Partnerstwo Wschodnie, również przyczyniły się do tego procesu. W związku z tym, projekt europejski może być uznany za przekonująco definiowany za pomocą modelu neośredniowiecznego.

W przypadku Rosji, obecna polityka wyklucza policentryczną wizję organizacji przestrzeni. Tylko Moskwa dominuje w znacznych częściach przestrzeni poradzieckiej. Jednakże działania rosyjskie mają inny wymiar niż czysto odbudowy imperium, jest to widoczne w koncepcji rosyjskiego państwa narodowego, zawierającego terytoria znajdujące się obecnie poza Federacją Rosyjską. Obecność silnej i licznej diaspory rosyjskiej w sąsiednich państwach prowokuje polityków do projektowania idei zjednoczenia narodu rosyjskiego i terytoriów rosyjskich w jednym państwie. Odnosi się to do przypadków mołdawskiego Naddniestrza, ukraińskiej Noworosji i Krymu, zachodniej Estonii i Łotwy, zachodniej Białorusi i północnego Kazachstanu (Kolstø, 1993). Projekt rosyjski byłby więc projektem zorganizowanym według modelu westfalskiego w najbardziej klasyczny sposób, mając na celu dostosowanie granic państwowych do realiów etnicznych, przy wykorzystaniu środków ekspansji terytorialnej.

Proponowane interpretacje mają ciekawe konsekwencje dla opisu relacji między obu projektami. Zderzenie dwóch inaczej zorganizowanych struktur skutkuje odwróconymi asymetriami. Projekt rosyjski organizowany jest na podobieństwo modelu westfalskiego (zwłaszcza w oparciu o zasadę państwa narodowego) i powinien być o wiele bardziej skuteczny w politykach zewnętrznych, zwłaszcza tych związanych z ustala- 
Schemat 6. Unia Europejska jako network vs. tworzenie rosyjskiego państwa narodowego
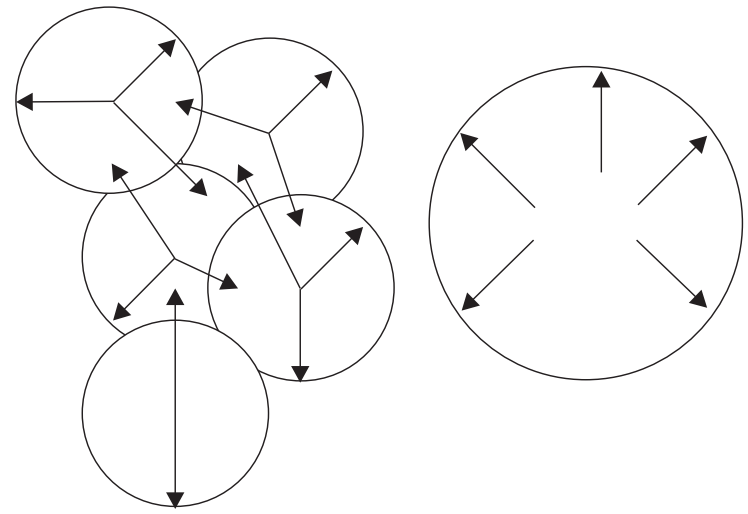

Źródło: Opracowanie własne.

niem granic i ich ochroną. Model neośredniowieczny projektu europejskiego ujawnia słabości w tym zakresie, wynikające ze znacznie bardziej skomplikowanego procesu negocjowania (często sprzecznych) interesów, co jest bardziej czasochłonne, ale także zwyczajnie skomplikowane. Dodatkowo dwie różne geostrategie sąsiadują ze sobą w tym przypadku. Projekt rosyjski (w przedstawionej wersji) w celu wdrożenia strategii limes definiuje wroga znajdującego się za linią graniczną. Sytuacja jest bardziej skomplikowana po stronie europejskiej. Strategia networked (non)border wydaje się dominować, jednak może ona okazać się niemożliwą do wdrożenia, będąc skonfrontowaną z geostrategią limes.

Przedstawione rozważania proponują klasyczne podejście do studiowania granic jako instrumenty przydatne dla zrozumienia aktualnych procesów granicznych na „krawędzi” Unii Europejskiej i Rosji. Zastosowanie koncepcji frontier i boundary, jak również geostrategii i modeli geopolitycznych Unii Europejskiej daje możliwość bardziej dogłębnej analizy problemu. Jednak to tylko inna niż UEcentryczna perspektywa, a tym samym uwzględnienie projektu integracyjnego istniejącego za wschodnią granicą Unii, pozwala zrozumieć naturę obserwowanych procesów. Jednocześnie należy zauważyć, iż proponowane wymiary analiz powinny zostać dalej rozwinięte, tak koncepcyjnie, jak i empirycznie, dla wykreowania przestrzeni dla dalszych rozważań.

\section{Bibliografia}

Agnew J. A. (2003), A World That Knows No Boundaries? The Geopolitics of Globalization and the Myth of a Borderless World, „CIBRWorking Papers in Border Studies”, No. 2.

Alkan N. (2002), Borders in Europe, w: Borders of Europe, (ed.) N. Alkan, Bonn.

Benedek M. (2003), From Neighbour to Member of Associate? The Future of the European Union's Neighbourhood Policy, „EU Policy Network”. 
Berg E., Ehin P. (2006), What Kind of Border Regime is in the Making? Towards a Differentiated and Uneven Border Strategy, „Cooperation and Conflict”, Vol. 41, No. 1.

Bernatowicz E. (2005), The Barcelona Process as an Instrument of EU Mediterranean Policy, „Polish Quarterly of International Affairs", No. 4.

Blockmans S., Hrant K., Vorobiov I. (2012), Towards a Eurasian Economic Union: The Challenge of Integration and Unity, „Centre for European Policy Studies Special Report”, No. 75.

Browning C. S., Joenniemi P. (2008), Geostrategies of the European Neighbourhood Policy, „European Journal of International Relations", Vol. 14, No. 3.

Caporaso J. A. (1996), The European Union and Forms of State: Westphalian, Regulatory or Post-Modern?, „Journal of Common Market Studies”, Vol. 34.

Cinciara A. (2008), 'Eastern Partnership'-opening a new chapter of Polish Eastern policy and the European Neighbourhood Policy, „Analyses and Opinions of the Institute of Public Affarirs”, No. 4.

Comelli M., Greco E., Tocci N. (2007), From Boundary to Borderland: Transforming the Meaning of Borders through the European Neighbourhood Policy, „European Foreign Affairs Review”, No. 12.

Delcour L., Wolczuk K. (2013), Beyond the Vilnius Summit: Challenges for Deeper EU Integration with Eastern Europe, „European Policy Centre Policy Brief”, 31 October.

Duke S. (2004), The Enlarged EU and the CFSP, ,Reports and Analyses of Center for International Relations", No. 5.

Evans G., Newnham J. (1998), The Penguin Dictionary of International Relations, London.

Germond B. (2010), From Frontier to Boundary and Back Again: The European Union's Maritime Margins', „European Foreign Affairs Review”, Vol. 15.

Jańczak J. (2010), Unia Europejska i jej granice. W poszukiwaniu modelu integracji na europejskich peryferiach, „Przegląd Politologiczny”, nr 4.

Jańczak J. (2013), Przesunięcie koncepcyjne w ,studiach granicznych”, „Przegląd Politologiczny”, $\mathrm{nr} 2$.

Jones S. B., (1959), Boundary Concepts in the Setting of Place and Time, „Annals of the Association of American Geographers", Vol. 49, Issue 3.

Klatt M., Hayo H. (2011), Half Empty of Half Full? Over 30 years of Regional Cross-Border Cooperation within the EU: Experiences at the Dutch-German and Danish-German Border, „Journal of Borderland Studies", Vol. 26, Issue 1.

Kolstø P. (1993), The New Russian Diaspora: Minority Protection in the Soviet Successor States, „Journal of Peace Research", Vol. 30, No. 2.

Kowal P. (ed.) (2002), The EU's ,Eastern Dimension”- An Opportunity or Idée Fixe of Poland's Policy?, Centrum Stosunków Międzynarodowych, Warszawa.

Kristof L. K. D. (1959), The Nature of Frontiers and Boundaries, „Annals of the Association of American Geographers", No. 3, Vol. 49.

Krotov I. (2011), Customs Union between the Republic of Belarus, the Republic of Kazakhstan and the Russian Federation within the framework of the Eurasian Economic Community, „World Customs Journal", Vol. 5, No. 2.

Lindberg L. N. (1963), The Political Dynamics of European Economic Integration, Stanford, CA.

Milczarek D. (2006), Eastern Dimension of the European Union's Foreign Policy, „Yearbook of Polish European Studies", No. 10.

Newman D. (2003), On borders and power: A Theoretical Framework, „Journal of Borderland Studies", Vol. 18, No. 1. 
O’Dowd L., Wilson T. (2002), Frontiers of sovereignty in the new Europe, w: Borders of Europe, (ed.) N. Alkan, Bonn.

Ojanen H. (1999), How to Customise Your Union. Finland and the Northern Dimension of the EU, „Northern Dimensions Yearbook”, Helsinki.

Scott J. (2013), Mapping Conceptual Change in Thinking European Borders, Call for Papers, Conference Bergamo, Italy, 3-5.07.2013.

Sekerev A. (2013), The EU Eastern Partners: Post-Vilnius domestic and foreign policy challenges, The Post-Vilnius Challenges of the Eastern Partnership, „The Eastern Partnership Review”, No. 15.

Süel A. (2008), From the Euro-Mediterranean Partnership to the Union for the Mediterranean, „Perceptions", Winter.

Szymczyński T. R. (2002), Modelowe założenia zasady elastyczności oraz próba kategoryzacji, w: Unia Europejska po Traktacie Nicejskim, (ed.) Z. Czachór, Warszawa.

Tolksdorf D. (2013), Die Östliche Partnerschaft nach dem Vilnius-Gipfel Ende November 2013. Zunehmende Konfrontation zwischen der Europäischen Union und Russland?, „Südosteuropa Mitteilungen", No. 6.

Walters W. (2004), The Frontiers of the European Union: A Geostrategic Perspective, „Geopolitics”, Vol. 9 , No. 3 .

Wind M. (2003), The European Union as a polycentric polity: returning to a neo- medieval Europe?, w: European Constitutionalism beyond the State, (eds.) J. H. H. Weiler, M. Wind, Cambridge.

Youngs R., Pishchikova K. (2013), Smart Geostrategy for the Eastern Partnership, Brussels.

Zielonka J. (2007), Europe as Empire. The Nature of the Enlarged European Union, Oxford.

\title{
STRESZCZENIE
}

Kryzys w relacjach Unii Europejskiej z Rosją w roku 2014 ujawnił koniec dotychczasowego modelu organizacji relacji granicznych między projektem europejskim i projektem rosyjskim. W efekcie konieczne jest stworzenie nowych schematów interpretacyjnych dla zrozumienia obecnej sytuacji politycznej. Prezentowana analiza proponuje powrót do klasycznego instrumentarium studiów granicznych i aplikacji rozumienia granicy jako frontier i boundary oraz spojrzenie na problem poprzez modele geopolityczne oraz geostrategie. Odejście od EUcentrycznego podejścia umożliwia stworzenie nowego schematu interpretacyjnego strukturyzacji granicy i pogranicza dwóch konkurencyjnych projektów integracyjnych.

\section{BORDER AND BORDERLAND OF THE EUROPEAN UNION AND RUSSIA. IN SEARCH FOR NEW INTERPRETIVE SCHEMES}

\begin{abstract}
Presented paper aims at proposing a new approach to understanding the current border relations between the European Union and Russia, by claiming, that changing political, economic and social circumstances has undermined the already dominating paradigms in studying borders. The new relations are based on competition, confrontation and even conflict, instead of collaboration. Consequently considerations presented propose to (re)employ classical instruments to
\end{abstract}


studying borders: concepts of frontier and boundary as well as the geostrategies and geopolitics of the EU. At the same time the non-EU-centric perspective, and including an alternative integration project behind the eastern border of the Union, allow to understand the nature of the observable border interactions. 